\title{
STUDY OF ACID-NEUTRALIZING CAPACITY OF THE DNIESTER RIVER UNDER WINTER LOW-WATER CONDITIONS
}

\author{
Olga Jurminskaia, Nina Bagrin, Elena Zubcov
}

Institute of Zoology, Chisinau, Republic of Moldova, e-mail: ojur_aia@mail.ru

\begin{abstract}
The resistance to acidification of the Dniester water was tested by the method of potentiometric titration. Water samples were collected on the right bank of the Dniester River within the territory of the Republic of Moldova in February 2020. The acid-neutralising capacity values obtained (ANC) were compared with the critical acid load (CAL), which makes it possible to assess the habitat conditions for any group of hydrobionts whose resistance to acidification is known
\end{abstract}

\section{Introduction}

Anthropogenic acidification of the environment became a spread phenomenon in the twentieth century and continues today, affecting not only the hydrosphere, but also the lithosphere and biota. Surface water ecosystems are most exposed, as acidification affects all their components, including water, bottom sediments and hydrobionts. Acidic precipitations alter the geochemical cycles of chemicals elements both in the catchment area and in the water body. An increase in acidity has negative consequences for the aquatic ecosystem, such as change in the ionic composition of water, the transition of metals from bound to free forms and, ultimately, a decrease in the buffer capacity of a water body.

The full buffer capacity is ensured by all components of water ecosystem: dissolved ions, suspended substances, bottom sediments, aquatic organisms, etc. In the world practice, various indicators are used to assess water acidification: $\mathrm{pH}$ dynamics, acidity, alkalinity, the ratio of concentrations of different ions and others. A method was proposed (Henriksen et al., 1992) for calculating the acid-neutralizing capacity (ANC) based on the content in water of such ions as $\mathrm{Ca}^{2}+, \mathrm{Mg}^{2}+, \mathrm{Na}+, \mathrm{K}+, \mathrm{SO}_{4}{ }^{2}-, \mathrm{NO}^{3}-, \mathrm{HCO}_{-}{ }^{-}, \mathrm{H}+$ and $\mathrm{Al}^{3}+$. This calculation method does not take into account the effects of such components of the aquatic habitat as suspended solids, polypeptides, polyphenols and organic acids (humic, fulvic), which are often present in surface waters. To assess the resistance to anthropogenic acidification of a water body, a method of potentiometric titration with graphic processing of the results obtained can also be used [1].

The Dniester River is one of the largest sources of fresh water in the Eastern Europe, with an average flow volume of about $10 \mathrm{~km} 3 /$ year. This is a transboundary river, a $652 \mathrm{~km}$ long section of which (Middle and Lower Dniester) is located on the territory of the Republic of Moldova or serves as a border with Ukraine. After the construction of the Dubossary dam and later the Novo-Dnestrovsc hydropower complex (Ukraine), the natural hydrological regime of the river was disrupted. As a result, three sections of the Dniester River within the territory of the Republic of Moldova have different hydrological and hydrochemical characteristics: the section downstream of the Dniester HPP-2, the Dubossary reservoir and the Lower Dniester downstream of the Dubossary dam. Climate change and flow regulation are not the only factors 
affecting the ecological state of the Dniester River. There is also modification of temperature and oxygen regimes, industrial and domestic pollution, exploitation of floodplain areas and destruction of natural habitats as a result of the extraction of sand and gravel.

The aim of the study was to analyze the acid-neutralizing capacity of the Dniester River water under conditions of alteration of the natural hydrological regime and climatic changes.

\section{Materials and methods}

Samples were collected at the Moldovan section of the Dniester River, which includes the sector downstream of the Dniester HPP-2 dam (stations Naslavcea, Valcinet, Soroca) and the sector downstream of the Dubossary dam (stations Vadul lui Voda and Varnita). "In situ", water temperature and hydrogen ion concentration $(\mathrm{pH})$ were measured using a CONSORT C5030 multi-parameter analyser with built-in temperature sensor. In laboratory, potentiometric titration was performed using a pH-meter SARTORIUS PB-11, a magnetic mini-stirrer HI 190M and a BLAUBRAND automatic burette 25/0.05. Processing the results of titration was carried out in MS Excel program. As noted above, the full buffer capacity of water body to acidification is ensured by all components of water ecosystem (dissolved substances, suspended solids, bottom sediments, hydrobionts, etc.). The partial buffer capacity of water to acid neutralizing due to dissolved and suspended substances (ANC, mmol/L) was determined by the titration curve at the $\mathrm{pH}$ inflection point (fig. 1) using the method [1]. The water samples were not preserved, filtered, diluted or concentrated. This method used for the acid-neutralising capacity of a water body is direct and does not require correction for the presence of suspended solids in the water. Also, there is no need to determine the entire composition of dissolved inorganic and organic substances involved in the neutralization of acidic pollution from rainfall and industrial wastewater.

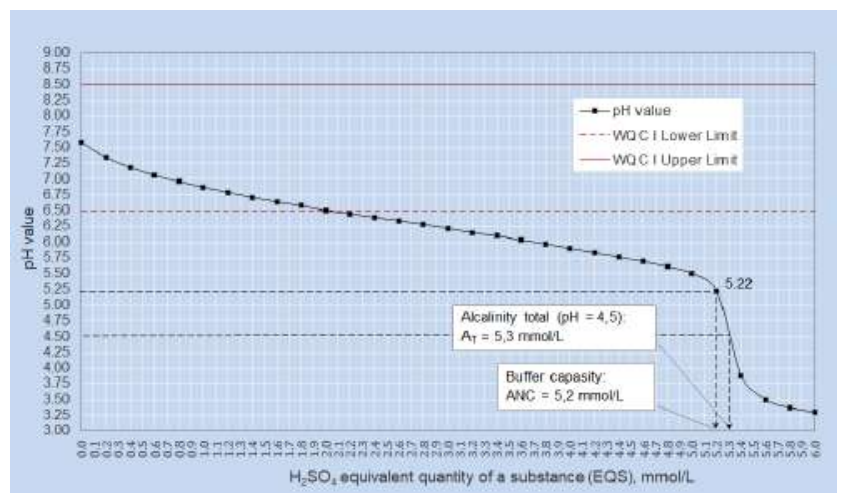

Figure 1. Assessing ANC and alkalinity by potentiometric titration curve (station Ustia, Feb 2020)

The sum of all titratable bases characterizes such hydrochemical parameter as alkalinity of water. Depending on the endpoint $\mathrm{pH}$ used, the composite alkalinity (AP, $\mathrm{pH} \geq 8.3$ ) or the total alkalinity ( $\mathrm{AT}, \mathrm{pH}=4.5$ ) is identified [2]. Because the total alkalinity of many surface waters is primarily a function of carbonates, bicarbonates and hydroxides, it also can be analyzed by the potentiometric titration curve at the endpoint $\mathrm{pH}=4.5$. When titrating to this $\mathrm{pH}$ value, all alkaline compounds in the water sample are used up. 


\section{Results and discussion}

The main components of a surface water body, which determine the values of such interrelated parameters as $\mathrm{pH}$, alkalinity and ANC (acid-neutralizing capacity), are carbonates $\left(\mathrm{CO}_{3}^{-}\right.$ $\left.{ }^{2}\right)$, bicarbonates $\left(\mathrm{HCO}_{3}-\right)$ and hydroxide ions $(\mathrm{OH}-)$. But not only the carbonate buffer system ensures the acid-neutralizing capacity of the aquatic habitat. Ammonia, borate, phosphate and silicate buffer systems, as well as organic anions, can also affect the resistance to acidification of a water body. The biological effect of acidification begins at a $\mathrm{pH}$ value $<6.5$ (water quality Lower Limit for freshwater ecosystems). The critical $\mathrm{pH}$ value below which the irreversible biological effects can occur is considered to be $5.6[2,3]$.

There are not many publications devoted to the study of the acid-neutralizing capacity of the Dniester River on the territory of Moldova. In the article by A. Lis et al. [4], a number of parameters characterising the buffer properties of the Dniester River and its tributaries were analysed: $\mathrm{pH}$, acidity, alkalinity, acid-base constant, etc. The acid-neutralizing capacity of the Dniester water were determined by potentiometric titration. The authors note insignificant seasonal fluctuations of tested parameters. Regarding resistance to acidification, the monitoring stations are ranked as follows: Cosauti $>$ Naslavcea $>$ Boshernita $>$ Dubossary Reservoir.

In the work of N. Goryacheva et al. [5], the acid-neutralizing capacity of the Dniester River was determined by Henriksen's method with calculation of the sum of hydrocarbonates and anions of organic acids $\left(\mathrm{ANC}_{1}=\mathrm{HCO}_{3}-+\mathrm{A}_{\text {org. }}\right)$ and the ionic balance of cations and anions $\left(\mathrm{ANC}_{2}=\mathrm{Ca}^{2+}+\mathrm{Mg}^{2+}+\mathrm{Na}^{+}+\mathrm{K}^{+}-\mathrm{SO}_{4}{ }^{2-}-\mathrm{Cl}^{-}-\mathrm{NO}_{3}^{-}\right)$. During the period $2008-2009$, a steady tendency towards water acidification downstream of the Buffer reservoir (Naslavcea station, $\mathrm{ANC}=2,42$ ) was observed. It was noted that the acid-neutralizing capacity of the Dniester water increased along the longitudinal profile of the river (Cosauti station from Soroca District, $\mathrm{ANC}=2,57$; Boshernita station from Rezina District, $\mathrm{ANC}=2,94)$, reaching its maximum values in the zone of the Dubossary dam $(\mathrm{ANC}=3,15)$. It was of interest to study how the buffer properties of the Dniester River have changed over the past decade, which was marked by global climate changes, aggravating the anthropogenic impact on natural ecosystems.

In our study, samples were collected from the surface water layer $0.8-1.0(\mathrm{~m})$ in the February 2020. In winter, the hydrological conditions of the Dniester River in the Republic of Moldova are characterized by low water level. Therefore, the concentration of industrial and domestic pollutants in water can be more critical than in summer. On the other hand, at low water temperatures, the productivity of hydrobionts is reduced. Thus, the influence of the biotic communities on the buffer capacity of the aquatic habitat is minimised during winter period. The temperature and acidification conditions $(\mathrm{pH})$ of the Dniester water at the time of sampling are presented in figure 2 . 

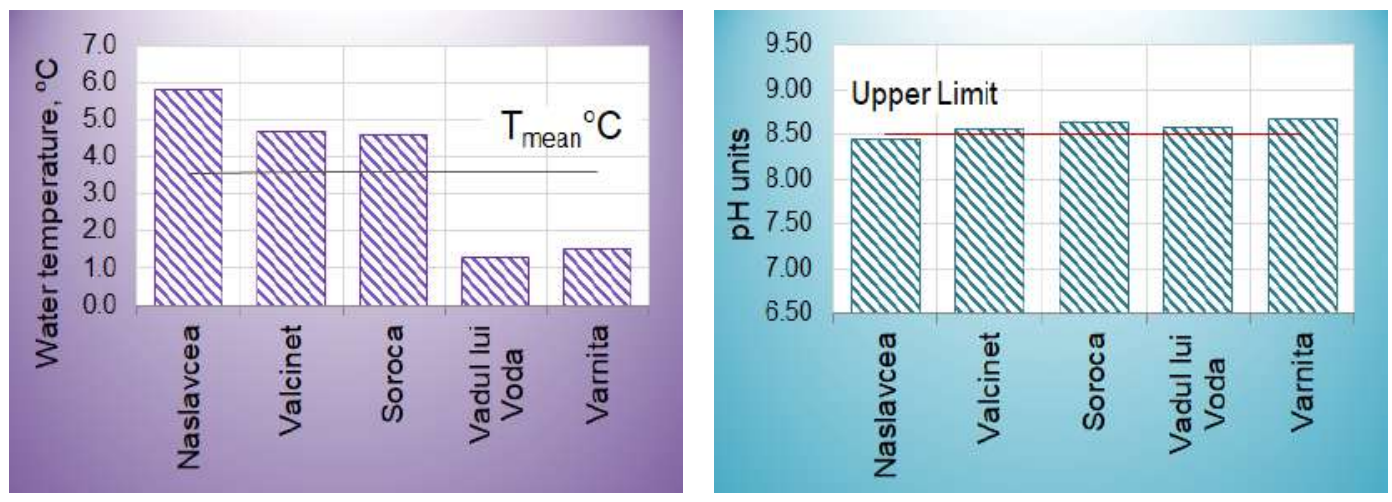

Figure 2. Dynamics of water temperature and $\mathrm{pH}$ values at the Dniester River monitoring stations

The concentration of hydrogen ions in the Dniester water varied in a narrow diapason 8.5 - 8.7 ( $\mathrm{pH}$ units), which includes the Upper Limit for the surface Water Quality Class I $(\mathrm{pH}=$ 8.5), regulated by the Decision of the Government of the Republic of Moldova No. 890 [6]. The average water temperature of the collected samples was $3.6^{\circ} \mathrm{C}$. The presented spatial dynamics of this parameter (as well as long-term investigations by the Laboratory of Hydrobiology and Ecotoxicology of the Institute of Zoology [7]) confirm the impact of the Dniester Hydropower Complex on the temperature regime of the Dniester River: winter water temperatures in the section downstream of HPP-2 (Naslavcea - Soroca) are higher than natural ones, while summer temperatures are lower.

Sampling over $400 \mathrm{~km}$ long river section and their delivery to the Laboratory takes at least 12 hours, therefore the potentiometric titration was carried out the next day. Until titration, the samples were stored in the dark at $3.6^{\circ} \mathrm{C}$ (average water temperature at the time of sampling). In winter biocenoses, the metabolic processes of hydrobionts are slowed down (respiration, growth, nutrition), but they do not stop even at this temperature. In the process of respiration and biochemical oxidation of substances dissolved in water, oxygen is consumed and carbon dioxide is released, which is the reason for a slight decrease of $\mathrm{pH}$ values in the water samples during the storage period (tab. 1).

Table 1. Decrease of $\mathrm{pH}$ in water samples due to metabolic processes

\begin{tabular}{|c|c|c|c|c|c|}
\hline pH value: & Naslavcea & Valcinet & Soroca & Vadul lui Voda & Varnita \\
\hline In situ & 8.45 & 8.55 & 8.64 & 8.57 & 8.68 \\
\hline In lab & 8.00 & 8.02 & 7.95 & 8.10 & 8.02 \\
\hline
\end{tabular}

When determining the resistance to acidification "in situ", the potentiometric titration curve will correspond to the instantaneous buffer capacity of the water body. Such results can be obtained using portable digital titrators. In our case, the burette method was implemented under standard laboratory conditions. 
To determine the partial buffer capacity, $100 \mathrm{~mL}$ of an unfiltered water sample was taken, transferred to a beaker, placed on a magnetic stirrer and titrated with a solution of H2SO4 0.02 $\mathrm{mol} / \mathrm{L}$. Sulfuric acid was chosen because it is predominant in acidic atmospheric precipitation. Some of titration curves with the values of ANC and total alkalinity are presented in fig. $3-5$.

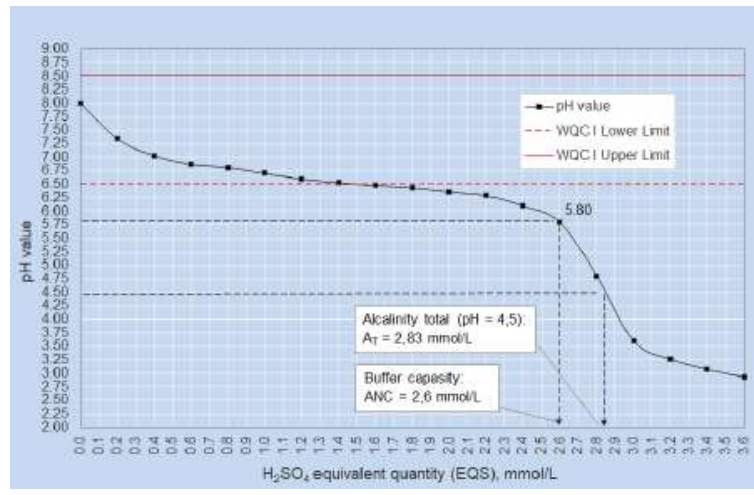

Figure 3. Assessing ANC and total alkalinity for station Naslavcea (February 2020)

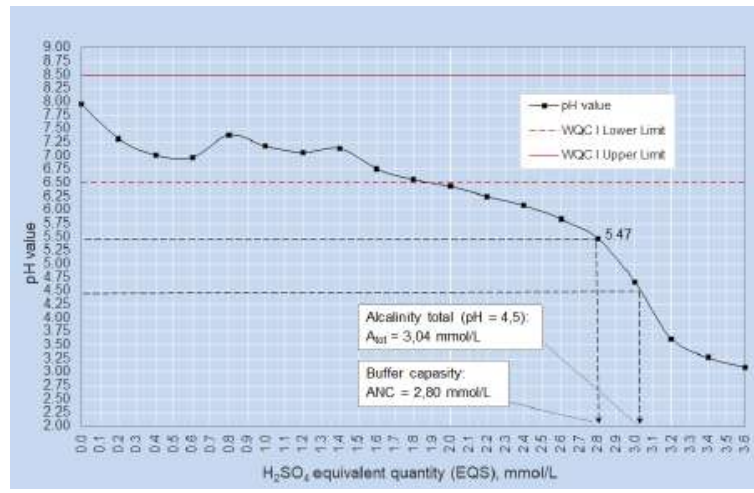

Figure 4. Assessing ANC and total alkalinity for station Soroca (February 2020)

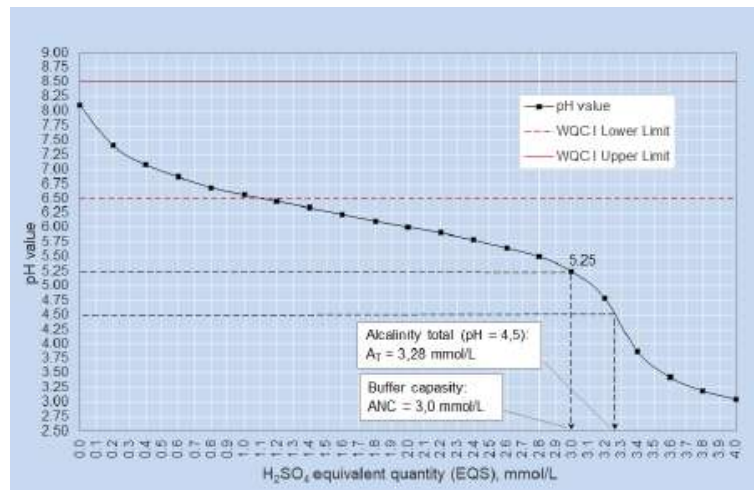

Figure 5. Assessing ANC and total alkalinity for station Vadul lui Voda (February 2020) 
As noted above and can be seen from the presented graphs, all tested samples at the beginning of potentiometric titration had a $\mathrm{pH}<8.3$. This means that the free carbonates present in water at the time of sampling have already undergone the first hydrolysis stage: $\mathrm{CO}_{3}{ }^{2-}+$ $\mathrm{H}_{2} \mathrm{O}=\mathrm{HCO}_{3}^{-}+\mathrm{OH}^{-}$. The buffer properties of the standard solution at this stage of titration with a strong acid are determined by the capacity of the buffer system $\mathrm{H}_{2} \mathrm{CO}_{3} / \mathrm{HCO}_{3-}$. Natural surface waters also contain other buffer systems, and the more there are, the more resistant to acidification the water body is, the more acid is required to reach the "inflection point" on the titration curve. The presented titration curves demonstrate that the acid-neutralizing capacity of the Dniester River (fig. 3 - 5) is lower than its tributaries (Fig. 1), in which, as a rule, the concentration of suspended solids, organic and inorganic components is higher. For practical purposes of observation monitoring, it is not even necessary to determine the "inflection point": it is enough to estimate the "point of Critical Acid Load" at $\mathrm{pH}=5.6$. A summary of the assessment results of the Dniester water buffer capacity parameters is presented in table 2.

Table 2. Buffer capacity parameters of the Dniester water in the winter low-water conditions

\begin{tabular}{l|c|c|c|c|c|}
\multicolumn{1}{c}{ Parameter } & Naslavcea & Valcinet & Soroca & V lui V & Varnita \\
\hline $\mathrm{pH}$ & & & 4.5 & & \\
\hline $\mathrm{A}_{\mathrm{T}}, \mathrm{mmol} / \mathrm{L}$ & 2.83 & 2.86 & 3.04 & 3.28 & 3.30 \\
\hline $\mathrm{pH}$ & & & 5.6 & & \\
\hline $\begin{array}{l}\mathrm{Critical} \text { Acid Load, } \\
\mathrm{mmol} / \mathrm{L}\end{array}$ & 2.65 & 2.50 & 2.75 & 2.70 & 2.75 \\
\hline $\mathrm{pH}$ & 5.80 & 5.42 & 5.47 & 5.25 & 5.54 \\
\hline $\mathrm{ANC}, \mathrm{mmol} / \mathrm{L}$ & 2.60 & 2.60 & 2.80 & 3.00 & 3.00 \\
\hline
\end{tabular}

\section{Conclusions}

The acid-neutralizing capacity of the Dniester River under the winter low-water conditions varies in the range of $2.60-3.00(\mathrm{mmol} / \mathrm{L})$. The vector of ANC gradient "min - max" coincides with the longitudinal profile of the river: the minimum value is in the section downstream of the HPP-2 (Naslavcea - Soroca), the maximum is downstream of the Dubossary dam (Vadul lui Voda - Varnita). The results were unexpected in the sense that the ANC values for all monitoring stations are in close proximity to the Critical Acid Load (CAL), estimated at $\mathrm{pH}=5.6$. Stations Naslavcea and Soroca (with all the difference in their hydrological and ecological characteristics) have the same lowest stability reserve to acidification: CAL - ANC $=0.05 \mathrm{mmol} / \mathrm{L}$. The highest is at Vadul lui Voda station: $0.30 \mathrm{mmol} / \mathrm{L}$. Thus, determining the acid-neutralizing capacity of the water body and comparing result with the Critical Acid Load makes it possible to assess habitat conditions for any group of hydrobionts whose resistance to acidification is known.

Determination of the Critical Acid Load of a water body can be used also in aquaculture for 
technological control of the cultivation conditions for hydrobionts with different thresholds of adaptation to habitat acidity.

The ability of an aquatic ecosystem to self-recover after anthropogenic impact is directly related to its buffering capacity. Today, the anthropogenic load on ecosystems is aggravated by climate change, and adaptation mechanisms do not have enough time to ensure the resistance of biotic communities to these pressures. Under such conditions, the biota loses its ability to stabilize the habitat, and the ecosystem becomes less productive. Rational use of water resources was the agenda of the last century. Today's attitude to natural ecosystems should be not just rational, but nature-saving.

Acknowledgment: Investigation was carried out within the project no. 20.80009.7007.06 AQUABIO (State Program 2020-2023) and of the international projects BSB 165 HydroEcoNex and BSB 23 MONITOX (Joint Operational Program Black Sea Basin 2014-2020 of the European Union).

\section{Bibliography}

1. Р52.24.701-2008 Методика оценки частичной буферной и частичной мгновенной буферной емкости водных объектов к закислению. Ростов-на-Дону: Росгидромет, ГУ ГХИ, 2008.

2. SM SR EN ISO 9963-1:2007 Calitatea apei. Partea 1: Determinarea alcalinității totale și permanente. MOLDOVA-STANDARD, Chișinău: 2007.

3. PH Requirements of Freshwater Aquatic Life. Technical Memorandum. Robertson-Bryan Inc., 2004, 15 p.

4. Lis A., Duca G., Bunduchi E., Gladchi V., Goreaceva N. The study of the buffering capacity of several water objects in the Republic of Moldova. In: Chemistry Journal of Moldova. General, Industrial and Ecological Chemistry. 2010, 5 (2), pp. 30 - 36.

5. Горячева Н., Гладкий В., Бундуки Е., Лис А. Анализ буферных свойств и уязвимости к закислению вод Среднего Днестра. În: Studia Universitatis Moldaviae, seria Științe reale și ale naturii, 2015, 1 (81), pp. $224-229$.

6. Regulament cu privire la cerințele de calitate pentru apele de suprafață. HG RM nr. 890 din 12.11.2013. Chișinău: Monitorul Oficial nr. 262 - 267, 22 noiembrie 2013.

7. Журминская О., Багрин Н., Зубкова Е. Оценка влияния гидростроительства на температурный и кислородные режимы Днестра в условиях климатических изменений. In: Hydropower impact on river ecosystem functioning: Proceedings of the International Conference, Tiraspol, Moldova, October 8-9, 2019, p. 101 - 106. 